Journal of Biotechnology and Strategic Health Research

Derleme / Review

http://dergipark.org.tr/tr/pub/bshr

\title{
COVID-19 Enfeksiyonunda Toraks Bilgisayarlı Tomografi Bulguları
}

\author{
Thorax Computed Tomography Findings in COVID-19 Infection
}

D Mustafa Özdemir¹, (D) Onur Taydaş², (D $\varangle$ M. Halil Öztürk²

\begin{tabular}{|c|c|c|}
\hline \multicolumn{3}{|c|}{ ORCID ID: Banu Karaca 0000-0003-1470-356X } \\
\hline \multicolumn{3}{|c|}{ ^Sorumlu Yazar / Corresponding Author: Prof. Dr. M. Halil Öztürk, e-posta / e-mail: ozturkmh@gmail.com } \\
\hline Geliş Tarihi / Received : 22-04-2020 & Kabul Tarihi / Accepted: 25-04-2020 & Yayın Tarihi / Online Published: 30-04-2020 \\
\hline $\begin{array}{l}\text { Atıf Gösterimi/How to Cite: Özdem } \\
\text { J Biotechnol and Strategic Health Res }\end{array}$ & $\begin{array}{l}\text { ydaş O., Öztürk M.H. COVID-19 Enfel } \\
\text { Özel Sayı):91-96 }\end{array}$ & da Toraks Bilgisayarlı Tomografi Bulguları, \\
\hline
\end{tabular}

Öz

2019 yeni koronavirüs hastalığı (COVID-19), tüm dünyaya yayılan önemli bir halk sağlığı sorunudur. Tanıda altın standart realtime reverse transcription polymerase chain reaction (RT-PCR) testi olsa da, özellikle klinik semptomu olup testin negatif geldiği hastalarda toraks bilgisayarlı tomografi (BT) önemli bir yol göstericidir. Bu derlemenin amacı, COVID-19'un tanısında giderek daha fazla kullanılan toraks BT'de saptanan bulguları özetlemektir.

Anahtar COVID-19, bilgisayarlı tomografi, radyoloji.

Kelimeler

\begin{tabular}{ll}
\hline Abstract & The 2019 new coronavirus disease (COVID-19) is an important public health issue that spreads worldwide. Though the gold standard real-time \\
reverse transcription polymerase chain reaction (RT-PCR) test is used in diagnosis, thorax computed tomography (CT) is an important guide \\
especially in patients with clinical symptoms and the test is negative. The purpose of this review is to summarize the findings found in thorax \\
CT, which is increasingly used in the diagnosis of COVID-19.
\end{tabular}




\section{GİRIŞ}

2019 yeni koronavirüs hastallğı (COVID-19), ağır akut solunumsal sendrom koronavirüs (SARS-CoV-2) nedeniyle oluşan ve ilk kez Çin'in Wuhan eyaletinde bildirilen bir enfeksiyon hastalığıdır. ${ }^{1}$ Daha sonraki süreçte hastalık önce Çin'de daha sonra da tüm dünyada yayılmış olup Dünya Sağlık Örgütü (WHO) tarafından da pandemi olarak ilan edilmiştir. ${ }^{2}$ En önemli klinik semptomları ateş ve öksürük olmakla birlikte yorgunluk, baş ağrısı ve nefes darlığı gibi semptomlar da görülebilir. Ancak tüm bu semptomların hastalığa spesifik olmaması ve hastalığın hızla ağır pnömoniye ilerleyebilmesi sebebiyle tanı testlerine ihtiyaç duyulmaktadır. ${ }^{3}$ COVID-19 tanısında viral nükleik asitlere yönelik yapılan "real-time reverse transcription polymerase chain reaction" (RT-PCR) testi altın standart olsa da yanlıs negatif sonuç verebilmesi nedeniyle tanıda bilgisayarlı tomografi (BT) giderek daha önemli hale gelmiştir. ${ }^{4}$ Yapılan çalışmalarda BT’nin duyarlılığının \%98'e ulaştığ 1 gösterilmiştir. ${ }^{5,6}$ Ancak özellikle iyonizan radyasyon içermesi nedeniyle BT bir tarama yönteminden ziyade RTPCR negatif olan ancak klinik olarak arada kalınan hastalarda sorun çözücü yöntem olarak kullanılmalıdır. ${ }^{7}$

$\mathrm{Bu}$ derlemenin amacı, önemli bir toplum sağllğı sorunu olan COVID-19'un tanısında giderek daha fazla kullanılan toraks BT'de saptanan bulguları özetlemektir.

\section{Görüntüleme Bulguları}

SARS-CoV-2 virüsünün insanlarda anjiyotensin dönüştürücü enzim 2 (ACE-2) reseptörleri üzerinden hücreye giriş yaptığı gösterilmiştir. Dolayısıyla virüs ilk olarak akciğerlerde intersitisyel hasar ve takiben parankim hasarına neden olmaktadır. ${ }^{8}$ Tanıda direkt göğüs radyografisinin duyarlılığı düşük olup normal bir grafi hastalığı dışlayamamaktadır. Bu nedenle tanıda kullanılması gereken yöntem kontrastsiz toraks BT'dir.' Toraks BT'de izlenen en önemli bulgular daha ziyade bazal yerleşimli, bilateral, periferal buzlu cam dansiteleridir. BT bulgularının daha yaygın şekilde tanınması sayesinde BT üzerinden çeşitli algoritmalar oluşturulmuştur. ${ }^{10}$ Bunun da ötesinde hastalığın şiddetini BT kullanarak değerlendiren skorlama sistemi de mevcuttur. ${ }^{11}$ Hastalığa ait tipik ve atipik bulgular tablo l'de özetlenmiştir. Derlememizde özellikle tipik bulgular görüntülerle zenginleştirilerek tartışılacaktır.

\begin{tabular}{|l|l|}
\hline $\begin{array}{l}\text { Tablo 1: COVID-19 enfeksiyonunda tipik ve atipik toraks bilgisayarlı } \\
\text { tomografi bulguları. }\end{array}$ \\
\hline Tipik & Atipik \\
\hline Buzlu cam opasitesi & Lenfadenopati \\
\hline Konsolidasyon & Plevral efüzyon \\
\hline Retiküler patern & Perikardiyal efüzyon \\
\hline $\begin{array}{l}\text { Arnavut kaldırımı } \\
\text { (Crazy paving) görünümü }\end{array}$ & Kavitasyon \\
\hline Hava bronkogramı & \\
\hline Havayolu değişiklikleri & \\
\hline $\begin{array}{l}\text { Nodüller (Halo ve ters halo bulgusu ile birlikte } \\
\text { olabilir.) }\end{array}$ & \\
\hline
\end{tabular}

\section{Buzlu Cam Opasitesi}

Akciğerlerde damar ve bronş duvarlarının silinmediği sis şeklindeki dansite artışları buzlu cam olarak tanımlanır. Hafif interstisyel kalınlaşma veya hava yollarının içerisinin dolarak havanın kaybolmasına bağlı gelişir. ${ }^{12}$ COVID-19 enfeksiyonu bulunan hastalarda tek taraflı ya da bilateral, periferal yerleşimli, subplevral buzlu cam opasiteleri sıklıkla görülür (Resim 1). ${ }^{13}$

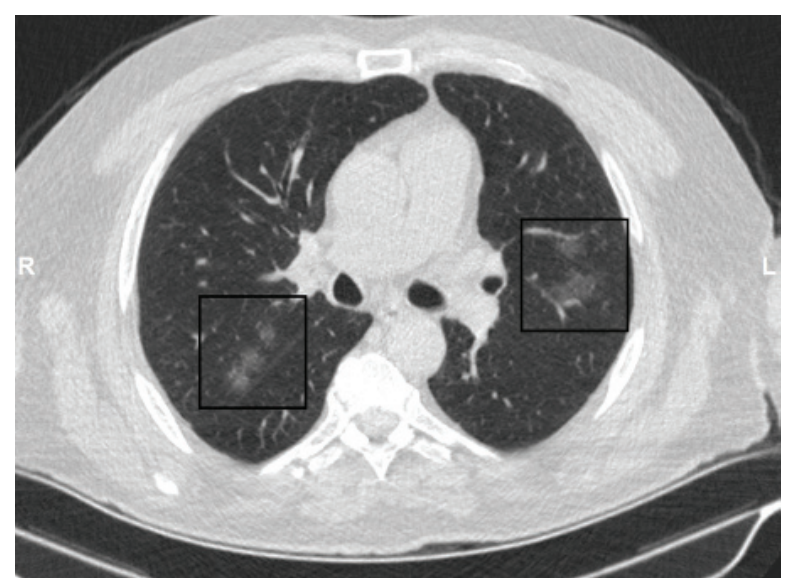

Resim 1: 64 yaşında erkek hastaya ait aksiyel kontrastsız toraks bilgisayarl tomografi görüntüsünde her iki akciğerde buzlu cam opasitesi izleniyor (çerçeveler). 
Salehi ve ark. tarafından yapılan ve 919 hastanın dahil edildiği bir metaanalizde buzlu cam opasitesi hastaların \%88'inde saptanmış olup en sık görüntüleme bulgusu olarak bildirilmiştir. ${ }^{14}$ İtalya'da yapılan bir çalışmada ise hastaların tamamında buzlu cam opasitesi bulunduğu saptanmıştır. ${ }^{15}$ Ayrıca buzlu cam opasitesinin hastalığın en erken radyolojik bulgusu olduğu bilinmektedir. ${ }^{16} \mathrm{Bu}$ görünümün akciğerdeki ödem ve hyalen membranlara bağlı olduğu düşünülmektedir. ${ }^{17}$ Buzlu cam opasitesi, tek başına görülebileceği gibi interlobüler septal kalınlaşma ve konsolidasyon gibi farklı bulgularla birlikte de görülebilmektedir. $^{18}$

\section{Konsolidasyon}

Konsolidasyon, alveol içerisindeki havanın yerini tamamıyla patolojik sıvı, hücre veya dokuların alması ve sonuçta gelişen dansite artışı olarak tanımlanır. Buzlu cam opasitesinden farkı, damar ve hava yollarının sınırlarının kaybolmasıdır. ${ }^{12}$ COVID-19 enfeksiyonu bulunan hastalarda genellikle multifokal, segmental, yamalı tarzda konsolidasyonlar görülür (Resim 2).

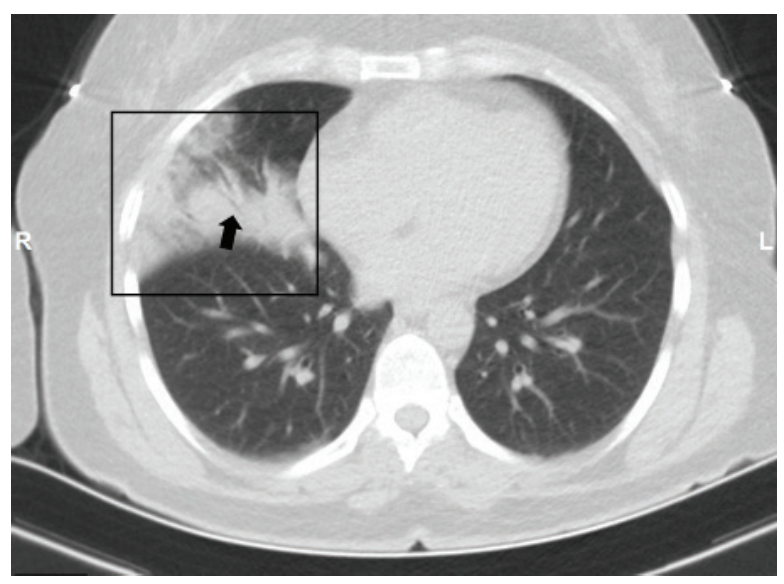

Resim 2: 61 yaşında kadın hastaya ait aksiyel kontrastsız toraks bilgisayarlı tomografi görüntüsünde să̆ akciğer orta lobda konsolidasyon (çerçeve) ve içerisinde hava bronkogramı (ok) izleniyor.
Genellikle subplevral veya peribronkovasküler yerleşim gösterirler. ${ }^{19}$ Patofizyolojik olarak bu hastalarda alveol içerisinde bulunan fibromiksoid yapıdaki eksuda ile ilişkili olduğu düşünülmektedir. ${ }^{20}$ Bunun dışında konsolidasyon varlığı, hastalığın prognozu ile ilişkili bulunmuş olup progresif hastalığın bir göstergesi olabilir. ${ }^{18}$

\section{Retiküler Patern}

İnterlobüler ve interlober septalar gibi intersitisyel yap1ların kalınlaşması olarak tanımlanmakta olup BT'de ince lineer dansiteler olarak izlenirler. ${ }^{12}$ İnterstisyel lenfosit infiltrasyonundan kaynaklandığı düşünülmektedir. ${ }^{17} \mathrm{CO}$ VID-19'da özellikle konsolidasyon ve buzlu cam opasitesi ile birlikte sık görülmekte olup hastalık süresi ilerledikçe artmaktadır (Resim 3). ${ }^{20}$

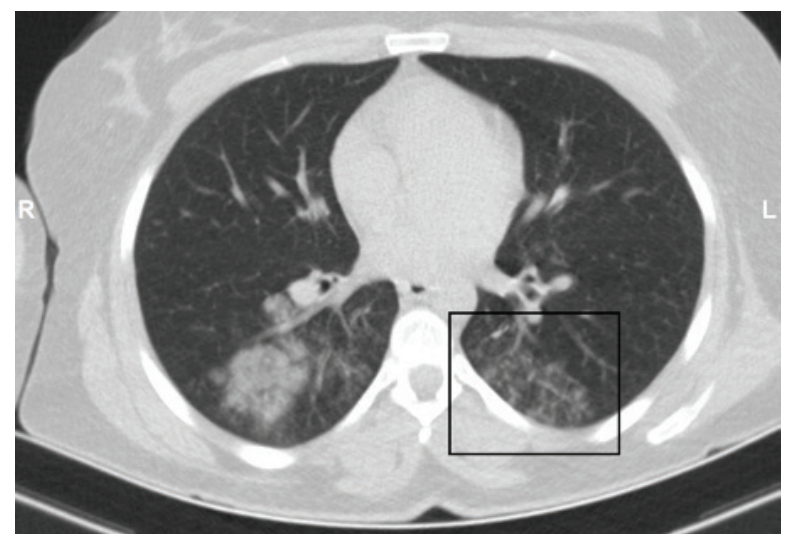

Resim 3: 73 yaşında kadın hastaya ait aksiyel kontrastsız toraks bilgisayarl tomografi görüntüsünde sol akciğer posteriorda retiküler patern izleniyor (çerçeve). Ayrıca hastanın diğer akciğerinde buzlu cam opasitesi mevcut.

\section{Arnavut Kaldırımı (Crazy Paving) Görünümü}

Kalınlaşmış interlobüler ve intralobüler septalar ile arka planda eşlik eden buzlu cam opasitesi olarak tanımlanır. ${ }^{12}$ Akut akciğer hasarındaki alveolar ödem ve interstisyel inflamasyon ile ilişkili olabilir. ${ }^{21}$ COVID-19'da konsolidasyon ve buzlu cam kadar sık görülmese de progresif hastalığın bir işareti olması hasebiyle önemlidir (Resim 4). ${ }^{22}$ 


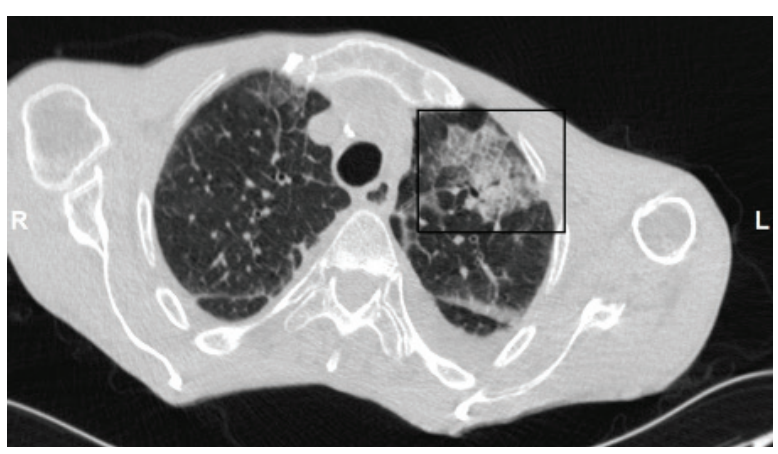

Resim 4: 70 yaşında erkek hastaya ait aksiyel kontrastsiz toraks bilgisayarl tomografi görüntüsünde sol akciğer üst lobda arnavut kaldırımı görünümü izleniyor (çerçeve).

\section{Hava Bronkogramı}

Düşük dansiteli, içi hava ile dolu bir bronşun arka planında yer alan yüksek dansiteli havalanmayan akciğer dokusunu ifade eden bir terimdir (Resim 2). ${ }^{12}$ COVID-19'da da izlenebilir ancak otopsi çalışmalarındaki bulgular bu hastalarda düşük dansitenin havadan değil bronşu dolduran jelatin benzeri mukustan kaynaklandığını göstermektedir. ${ }^{17}$ Bu bulgu hafif bronşiol dilatasyonuna eşlik edebilir ve bu durumda bronşiolektazi olarak da isimlendirilebilir. ${ }^{13}$

\section{Havayolu Değişiklikleri}

COVID-19'da izlenen havayolu değişiklikleri bronşiektazi ve bronş duvar kalınlaşmasını içerir ve bronş duvar kalınlaşması daha sık görülür. ${ }^{4}$ Patofizyolojik olarak bronş duvarındaki inflamatuar hasar ve bronş tıkanıklığı sonrasında gelişen bronş duvarının parçalanması ve sonucunda oluşan fibrozise bağlıdır. ${ }^{12}$ Özellikle bronş duvar kalınlaşması kötü prognoz ile ilişkili bulunmuştur. ${ }^{23}$

\section{Nodüller}

Tanım olarak yuvarlak veya düzensiz sınırlı 3 cm'den küçük dansitelerdir. ${ }^{12}$ Viral pnömonilerde sık rastlanan bir bulgu olup COVID-19'da da multifokal, solid, düzensiz sınırlı nodüller görülebilir (Resim 5). ${ }^{6,22}$ Ayrıca halo işareti ve ters halo işareti de görülebilir. ${ }^{23,24}$ Halo işareti, bir nodül veya kitlenin buzlu cam opasitesi ile çevrelenmesi şeklinde tanımlanır (Resim 6). Patofizyolojik olarak peri- lezyonel kanamayı temsil eder. ${ }^{25}$ Ters halo işareti veya atoll işareti ise buzlu cam opasitesini saran konsolidasyon olarak tanımlanır (Resim 7). İlk olarak organize pnömonide tanımlanmış olmakla birlikte başka pek çok hastalıkta da görülebilir. ${ }^{26}$ Patofizyolojik olarak hastalığın ilerlemesi ile lezyonun merkezindeki debrisin çözülmesi sonucu oluştuğu düşünülmektedir. ${ }^{27}$

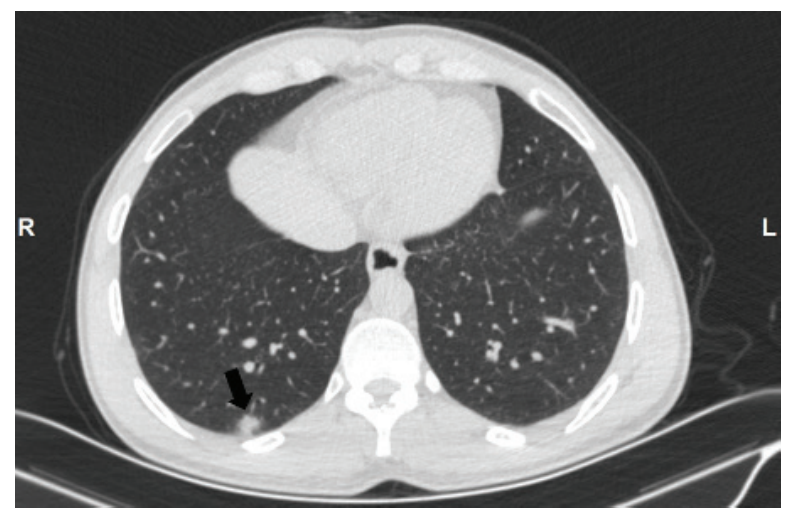

Resim 5: 68 yaşında erkek hastaya ait aksiyel kontrastsız toraks bilgisayarl tomografi görüntüsünde sağ akciğer alt lob posteriorda düzensiz konturlu nodül izleniyor (ok).

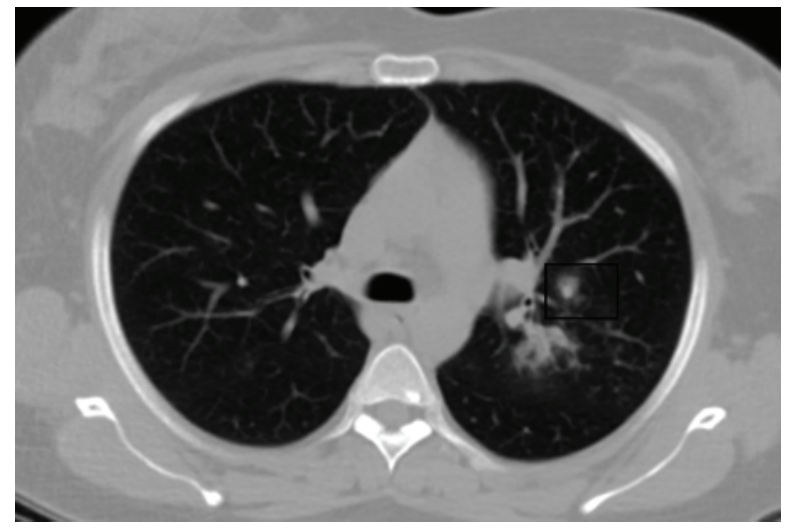

Resim 6: 40 yaşında kadin hastaya ait aksiyel kontrastsız toraks bilgisayarl tomografi görüntüsünde sol akciğer üst lobda izlenen nodül ve çevresindeki buzlu cam opasitesi halo işareti ile uyumlu görünüm oluşturuyor (çerçeve). 


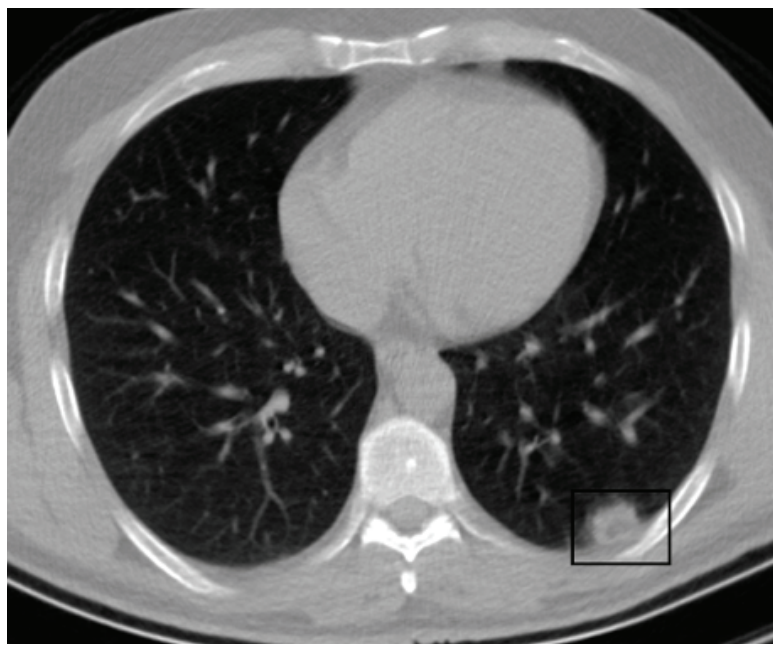

Resim 7: 45 yaşında erkek hastaya ait aksiyel kontrastsız toraks bilgisayarl tomografi görüntüsünde sol akciğer posteriorda izlenen buzlu cam opasitesini saran konsolidasyon ters halo işareti ile uyumlu görünüm oluşturuyor (çerçeve).

\section{Atipik Bulgular}

Lenfadenopati, kavitasyon, plevral ve perikardial efüzyon COVID-19'da oldukça nadir izlenmekte olup RT-PCR pozitif hastlarda eşlik eden bakteriyel enfeksiyon düşündürmelidir. ${ }^{13}$

\section{SONUÇ}

COVID-19'un erken tanısı pandeminin yayılmasının durdurulabilmesi için hayati öneme sahiptir. Her ne kadar hastalığın tipik toraks BT bulguları bilateral buzlu cam dansiteleri olsa da farklı bazı bulguların da görülebileceği akılda tutulmalıdır. 
J Biotechnol and Strategic Health Res. 2020;1(Özel Sayı):91-96

ÖZDEMİR, TAYDAȘ, ÖZTÜRK, COVID-19 Enfeksiyonunda Toraks BT

\section{Kaynaklar}

1. Zhu N, Zhang D, Wang W, Li X, Yang B, Song J, Zhao X, Huang B, Shi W, Lu R, Niu P, Zhan F, Ma X, Wang D, Xu W, Wu G, Gao GF, Tan W. A Novel Coronavirus from Patients with Pneumonia in China, 2019. N Engl J Med. 2020; 382: 727-733.

2. COVID C, Team R. Severe outcomes among patients with coronavirus disease 2019 (COVID-19)-United States, February 12-March 16, 2020. MMWR Morb Mortal Wkly Rep. 2020; 69: 343-346.

3. Akcay MS. Radiological Approaches to Covid-19 Pneumonia. Turk J Med Sci. 2020.

4. Xie X, Zhong Z, Zhao W, Zheng C, Wang F, Liu J. Chest CT for Typical 2019-nCoV Pneumonia: Relationship to Negative RT-PCR Testing. Radiology. 2020: 200343.

5. Fang Y, Zhang H, Xie J, Lin M, Ying L, Pang P, Ji W. Sensitivity of Chest CT for COVID-19: Comparison to RT-PCR. Radiology. 2020: 200432

6. Ai T, Yang Z, Hou H, Zhan C, Chen C, Lv W, Tao Q, Sun Z, Xia L. Correlation of Chest CT and RT-PCR Testing in Coronavirus Disease 2019 (COVID-19) in China: A Report of 1014 Cases. Radiology. 2020: 200642.

7. Erturk SM. CT of Coronavirus Disease (COVID-19) Pneumonia: A Reference Standard Is Needed. AJR Am J Roentgenol. 2020: W1.

8. Xu X, Chen P, Wang J, Feng J, Zhou H, Li X, Zhong W, Hao P. Evolution of the novel coronavirus from the ongoing Wuhan outbreak and modeling of its spike protein for risk of human transmission. Sci China Life Sci. 2020; 63: 457-460.

9. Kanne JP, Little BP, Chung JH, Elicker BM, Ketai LH. Essentials for Radiologists on COVID-19: An Update-Radiology Scientific Expert Panel. Radiology. 2020: 200527.

10. Nair A, Rodrigues JCL, Hare S, Edey A, Devaraj A, Jacob J, Johnstone A, McStay R, Denton E, Robinson G. A British Society of Thoracic Imaging statement: considerations in designing local imaging diagnostic algorithms for the COVID-19 pandemic. Clin Radiol. 2020; 75: 329-334.

11. Yang R, Li X, Liu H, Zhen Y, Zhang X, Xiong Q, Luo Y, Gao C, Zeng W. Chest CT Severity Score: An Imaging Tool for Assessing Severe COVID-19. Radiology: Cardiothoracic Imaging. 2020; 2: e200047.

12. Hansell DM, Bankier AA, MacMahon H, McLoud TC, Muller NL, Remy J. Fleischner Society: glossary of terms for thoracic imaging. Radiology. 2008; 246: 697-722.

13. Ye Z, Zhang $Y$, Wang $Y$, Huang Z, Song B. Chest CT manifestations of new coronavirus disease 2019 (COVID-19): a pictorial review. Eur Radiol. 2020.

14. Salehi S, Abedi A, Balakrishnan S, Gholamrezanezhad A. Coronavirus Disease 2019 (COVID-19): A Systematic Review of Imaging Findings in 919 Patients. AJR Am J Roentgenol. 2020: $1-7$.
15. Caruso D, Zerunian M, Polici M, Pucciarelli F, Polidori T, Rucci C, Guido G, Bracci B, de Dominicis C, Laghi A. Chest CT Features of COVID-19 in Rome, Italy. Radiology. 2020: 201237

16. Chung M, Bernheim A, Mei X, Zhang N, Huang M, Zeng X, Cui J, Xu W, Yang Y, Fayad ZA, Jacobi A, Li K, Li S, Shan H. CT Imaging Features of 2019 Novel Coronavirus (2019-nCoV). Radiology. 2020; 295: 202-207.

17. Xu Z, Shi L, Wang Y, Zhang J, Huang L, Zhang C, Liu S, Zhao P, Liu H, Zhu L, Tai Y, Bai C, Gao T, Song J, Xia P, Dong J, Zhao J, Wang FS. Pathological findings of COVID-19 associated with acute respiratory distress syndrome. Lancet Respir Med. 2020; 8: 420-422.

18. Song F, Shi N, Shan F, Zhang Z, Shen J, Lu H, Ling Y, Jiang Y, Shi Y. Emerging 2019 Novel Coronavirus (2019-nCoV) Pneumonia. Radiology. 2020; 295: 210-217.

19. Wu J, Wu X, Zeng W, Guo D, Fang Z, Chen L, Huang H, Li C. Chest CT Findings in Patients With Coronavirus Disease 2019 and Its Relationship With Clinical Features. Invest Radiol. 2020; $55: 257-261$

20. Shi $\mathrm{H}$, Han X, Jiang N, Cao Y, Alwalid O, Gu J, Fan Y, Zheng C. Radiological findings from 81 patients with COVID-19 pneumonia in Wuhan, China: a descriptive study. Lancet Infect Dis. 2020; 20: 425-434.

21. Wong KT, Antonio GE, Hui DS, Lee N, Yuen EH, Wu A, Leung CB, Rainer TH, Cameron $P$, Chung SS, Sung JJ, Ahuja AT. Thin-section CT of severe acute respiratory syndrome: evaluation of 73 patients exposed to or with the disease. Radiology. 2003; 228: 395-400.

22. Pan F, Ye T, Sun P, Gui S, Liang B, Li L, Zheng D, Wang J, Hesketh RL, Yang L, Zheng C. Time Course of Lung Changes On Chest CT During Recovery From 2019 Novel Coronavirus (COVID-19) Pneumonia. Radiology. 2020: 200370.

23. Li K, Wu J, Wu F, Guo D, Chen L, Fang Z, Li C. The Clinical and Chest CT Features Associated with Severe and Critical COVID-19 Pneumonia. Invest Radiol. 2020.

24. Xu R, Du M, Li L, Zhen Z, Wang H, Hu X. CT imaging of one extended family cluster of corona virus disease 2019 (COVID-19) including adolescent patients and "silent infection". Quant Imaging Med Surg. 2020; 10: 800-804.

25. Pinto PS. The CT Halo Sign. Radiology. 2004; 230: 109-10.

26. Taydas O, Erarslan Y, Atceken Z, Ariyurek OM. Granulomatoz polianjitte (Wegener granulomatozu) toraks BT bulguları. Türk Radyoloji Derg. 2017; 36: 86-88.

27. Kim SJ, Lee KS, Ryu YH, Yoon YC, Choe KO, Kim TS, Sung KJ. Reversed halo sign on high-resolution CT of cryptogenic organizing pneumonia: diagnostic implications. AJR Am J Roentgenol. 2003; 180: 1251-4. 